\title{
PERCEPTION AND MOTIVATION OF CHRISTIAN STUDENTS TO CHOOSE MUHAMMADIYAH UNIVERSITY: PLURALISTIC EDUCATIONAL PERSPECTIVE OF MUHAMMADIYAH
}

\author{
Imam Pribadi ${ }^{1}$, Asriany ${ }^{2}$ \\ 1,2Universitas Muhammadiyah Palopo \\ 1,2Jalan Jend. Sudirman KM. 3 Binturu, Kota Palopo \\ Email: imampribadi82@gmail.com ${ }^{1}$, asrigb@yahoo.com ${ }^{2}$
}

\begin{abstract}
:
Religious plurality must be interpreted as plurality and multireligiousism in the nation's life and state. This research aimed to investigate Christian students' perception and motivation to study at Muhammadiyah University in Palopo. It was qualitative research with a phenomenological approach, which was conducted at Muhammadiyah University of Palopo. Five non-Muslim students were selected based on the purposive sampling technique, and the researchers became the main instruments. Other supporting instruments were interview guidelines, observation sheets, and tape recorders. The data collection techniques used are observation, in-depth interview, and documentation. The researchers made data reduction, data display, and drawing conclusions or verification in analyzing the data. The findings obtained revealed that Christian students' perception and motivation in enrolling Muhammadiyah University of Palopo was majorly affected by the support of parents, families, self-motivation, and their major at Muhammadiyah University of Palopo.
\end{abstract}

\begin{abstract}
Abstrak:
Pluralitas agama merupakan suatu hal yang harus dimaknai sebagai kemajemukan dan multireligius dalam kehidupan berbangsa dan bernegara. Penelitian ini bertujuan untuk mengetahui persepsi dan motivasi mahasiswa Kristen dalam memilih Universitas Muhammadiyahdi Palopo. Pendekatan metode yang digunakan adalah kualitatif yang bercorak fenomenologi. Penelitian ini dilakukan di Universitas Muhammadiyah Palopo. Jumlah sampel yang digunakan yaitu 5 mahasiswa non muslim, dengan teknik pemilihan purposive sampling. Instrumen dalam penelitian ini yaitu peneliti itu sendiri sebagai instrumen utama, adapun instrument pendukung yaitu pedoman wawancara, lembar observasi, dan tape recorder. Teknik pengumpulan data yang digunakan yaitu observasi, wawancara mendalam (indepth interview), dan dokumentasi. Adapun analisis data yang digunakan yaitu reduksi data, displaydata dan pengambilan kesimpulan atau verifikasi. Hasil penelitian yang diperoleh bahwa Persepsi dan motivasi mahasiswa Kristen dalam memilih Universitas Muhammadiyah Palopo sebagian besar dipengaruhi oleh dukungan orang tua, keluarga, motivasi dalam diri, dan jurusan yang diinginkan ada di Universitas Muhammadiyah Palopo.
\end{abstract}

\section{Keywords:}

Pluralistic, Education, Perception, Motivation

How to Cite: Pribadi, I. \& Asriany. (2021). Perception and Motivation of Christian Students to Choose Muhammadiyah University: Pluralistic Educational Perspective of Muhammadiyah. Lentera Pendidikan : Jurnal Ilmu Tarbiyah dan Keguruan, 24(1), 1-11. https://doi.org/10.24252/lp.2021v24n1i1. 


\section{INTRODUCTION}

Indonesia is an archipelago consisting of various tribes, languages, social, cultural, and religious. Indonesian society is a diverse community. Asroni (2007) believed that the differences and diversities are inevitable sunattullahs on this life. Wakhidah \& Adityarini (2020) argued that diversity is the challenge that must be faced first, especially when trying to adapt to new environments. Faas, Darmody, \& Sokolowska (2015) described that Rising populations and the arrival of new migrants who bring diverse cultures and religions appeared new challenges for schools in Ireland.

As a plural and heterogeneous country, Indonesia has the wealth potential in multiethnic, multicultural, and multireligious, which is useful for building a large multicultural nation-state (Lestari, 2016). In Nigeria, Dowd (2015) argued that religious leaders encourage religious tolerance openly.

Soetapa (1991) argued that "...diversity can be a disaster for the Indonesian nation because it can be a source and potential conflict that can disrupt and even threaten the national unity." The community plurality that exists in Indonesia is an undeniable invitation. Therefore, committing to maintain diversity becomes the only possible way. Amirsyah (2012) added that no one could tolerate any form of action that can destroy this plural community (diversity community).

The issue and discourse of pluralism in this research becomes a very important national issue discussed in Tanfidz of the 47th of Muhammadiyah Muktamar Decree, which took the theme Diversity and Tolerance (Tanfidz, 2015). It is then thoroughly explained that Indonesia is a very religious nation with obedience to worship and has a good tolerance attitude. Tolerance is deeply rooted in attitudes and behaviors, in social interactions of mutual respect and cooperation among different religions. Nashir (2006) suggested that Muhammadiyah ideology is a system of understanding, philosophy, or world view that underlies the struggle to carry out the movement to achieve the goals.

Religious plurality itself, Pajarianto \& Mahmud (2019) argued that it is an obligation that Indonesian must understand due to the coexist with multireligious. Muhammadiyah, as one of the religious organizations, has shown responses that some members gave a positive appreciation to pluralism and others refused. The public figures of Muhammadiyah, such as Ahmad Syafii Maarif, Amin Abdullah, Abdul Munir Mulkhan, and Muslim Abdurrahman, can be known as the representation of Muhammadiyah thinkers who are very appreciative of pluralism. At the same time, some Muhammadiyah activists rejected pluralism, such as Muhammad Muqodas, Yunahar Ilyas, and Musthafa Kamal Pasha. Ilyas (2005) argued that the repellents believed that the idea of pluralism and liberalism contradicts the teachings of Islam. Even the discourse of pluralism among Muhammadiyah is considered causing uneasiness.

Anwar (2018) stated that the Central Leadership Tarjih Assembly defines pluralism as a worldview, philosophy, ideology, or understanding as one of the principles looking at other religions and relationships among religious people. Meanwhile, Kuntowijoyo (2008) analyzed pluralism by using the view of Proficient Social Sciences by rejecting pluralism 
that indicates a tendency to move, mix, and hide religious beliefs by referring to it as negative pluralism. On the contrary, the people who confirm their religions' truth but can accept different beliefs are called ideal coexistence or positive pluralism. Biyanto (2014) defined positive pluralism as a religious attitude that prioritizes respect for opinions, life choices, and beliefs. To realize harmonious religious pluralism, it must face an intense process and get support from other religions (Yahya, 2010).

Muhammadiyah became an important pillar of civil society and pioneered the new era of democratic Indonesia in the Reformation era, respected human rights, became insightful, and be responsive and critical to the government based on Muhammadiyah's personality (Tanfidz, 2010). In its implementation, Mu'ti (2016) defined that Muhammadiyah institutions accept students regardless of their religious background, ethnicity or ethnicity, nationality, and economy.

It is known that university students become one of the moral forces of the nation. They are a large number of the intellectual part of the country that can influence social change as well as corrective forces and the originator of public awareness of the rulers' negligence in its duty to organize government as well as as the source of the organization of struggle (Pribadi, Halim, Batlajery, \& Raf, 2019).

\section{RESEARCH METHOD}

This research applied qualitative through a phenomenological approach, which was conducted at Muhammadiyah University of Palopo. Five non-Muslim students were selected through purposive sampling techniques. The sample criteria in this study are nonMuslim students who are active in college. The researchers become the primary instruments, while the secondary instruments are interview guidelines, observation sheets, and tape recorders. The data collection techniques were conducted through observation, in-depth interviews, and documentation, then analyzed using data reduction, data display, and drawing conclusion or verification.

\section{RESULTS AND DISCUSSION}

Identifying Christian students' perception and motivation in enrolling Muhammadiyah University was conducted to analyze their perception of the pluralistic model of Muhammadiyah education. This identification consisted of several categories, ranging from chronology in selecting a university, best decisions, family support, and decision-making until their expectation after graduating from Muhammadiyah University of Palopo. Some informants have been analyzed about their perception of the educational models in Muhammadiyah. The researchers gave them initial, namely: APR, CSY, RZW, TA, and FEB.

Kurnianto \& Kasturi (2016) believed that deciding to enoll Muhammadiyah University is an uneasy decision for non-Muslim students. The complex considerations in determining to study at Islamic universities are caused by family, relatives, peers, and their initiatives. Then, if they failed to determine the study plan, they would impact their lives.

PERCEPTION AND MOTIVATION OF CHRISTIAN STUDENTS TO CHOOSE MUHAMMADIYAH (IMAM \& ASRIANY) 3 
It is in line with Pratiwi (2009), who stated that making decisions is an individual process and is useful to solve their daily problems.

Based on the research findings, the information was obtained from the first informant initials APR (22 years), who said that he/she found difficulty when choosing and determining continuing his/her study. He/she stated that he/she needed to take a break time for one year before continuing his study to strengthen his/her choice. APR's used the time to find out a little bit of information about the campus that fulfils his/her criteria. Then, he/she decided to continue his/her study without leaving Palopo city. His/her relative recommended him to join Muhammadiyah University of Palopo, but APR considered it due to the Islamic University-based. Therefore, the informant took the initiative to seek information related to the campus. APR obtained information that Muhammadiyah University of Palopo fulfils his criteria. He/she got support from his family and associates about his/her decision to continue study at Muhammadiyah University of Palopo. Another reason for choosing Islamic university was to add his/her critical views to be a success after graduation. His/her statement was in the same line with Tamrin (2019) that non-Muslim students were passionate about attending courses at Muhammadiyah University. He/she also expected to increase their insight at Muhammadiyah University of NTT, which was proven by their full attendance.

CSY's as the second informant (21 years), said that he/she found difficulty in deciding to continue the study. It was due to the warnings from his/her family not to continue his/her education outside of Palopo City in accordance with being far away from the family. Therefore, CSY decided to continue his study in Palopo and chose Muhammadiyah University of Palopo. CSY worried about treating discriminatory, but he/she got positive support from his/her family, which caused him/her to become more excited and get confident in his/her choice. Kurnianto \& Kasturi (2016) justify CSY's decision by their research result that several factors influence non-Muslim students' decision to study in Islamic University, including motivation, university image, considering options and seeking information, having goals and expectations. Another reason why informants decided to continue their studies at Muhammadiyah University of Palopo because the campus provides the majority that CSY wanted. CSY expected that he/she would get a lot of insight into anything and became an honest and disciplined person. Also, the informant was expected to achieve success after graduating from that campus. It was in line with Kahar \& Pabalik (2018), who revealed in their observation that non-Muslim students already got religious attitudes, honesty, hard work, discipline, consistency, and good tolerance after getting Islamic Teaching of Muhammadiyah integration values about Islam.

The third informant, initially TA (19 years), had the same opinion as to the previous informant. The informant firstly wanted to continue his/her study outside the city, but he/she also did not want to be far away from his family. Getting some considerations, the informant decided to continue his education at Muhammadiyah University of Palopo, which provided a course that matched with what the TA informant expected. Firstly, 
his/her decision was constrained by his status as a non-Muslim. Having the information that the campus was also available for non-Muslim students made him more confident to continue his/her study and support his/her parents. He believed that he could continue his/her education without being far away from his parents. Studying at Muhammadiyah University of Palopo, he/she could achieve his/her expectation to become a teacher. Utami (2018), in her research, justify that one of the main factors in continuing study in university for non-Muslim is parents' support.

The fourth informant, RZW (19 years old), revealed that he/she had no difficulty in choosing a university because one of his/her families was studying at Muhammadiyah University of Palopo. Even with different majors, he/she did not hesitate to join the same way. The decision was supported by his/her parents, especially from his/her father. Moreover, the department of RZW's intending was available in Muhammadiyah University of Palopo, so the informant was steady of his/her decision. The informant's expected to become a teacher after completing the study at Muhammadiyah University of Palopo. Mariati (2017) strengthened RZW's decision on her research that parents' support influenced non-Muslim students to select a study program in Tarbiyah and Teaching Training Faculty at UIN Syarif Kasim. Three non-Muslim students got motivation from their friends, and only two non-Muslim students said their self-motivation influenced the decision.

The fifth informant, initially FEB (19 years old), stayed firmly on his/her decision about continuing the study at Muhammadiyah University of Palopo when he/she got a failure to enroll in two universities. He/she decided to join Muhammadiyah University of Palopo because it was the only one available for new student enrollment. The decision that he/she took raised questions from his family following his/her status as non-Muslim. The informant (FEB) gave understanding about it, and he/she finally got support from family, especially from his/her brother. Shakeel (2018), who research it, justified the informant's case that the child's school's decision was influenced by the choice and support of the family, especially by parents. Also, the reason for choosing Muhammadiyah University of Palopo was as same as the CSY informant that the campus was the only one that provided the expected major so that he/she could achieve success in being a professional accountant.

The interviews result from five informants showed that Christian students' perception and motivation in choosing Muhammadiyah University of Palopo were influenced by some factors such as their parents, families, self-motivation, and the expected major at Muhammadiyah University of Palopo. In the following, we attach a table of Christian student perceptions to choose Muhammadiyah universities:

\section{Problem Identification: Difficulties When Choosing Colleges}

Table 1: Interview Result Problem Identification: Difficulties When Choosing Colleges

Informant

$\begin{array}{cl}\mathrm{APR} \pm 22 \text { years Old } & \text { I was unemployed for one year, but a high school } \\ \text { Women } & \text { classmate suggested that if you wanted to go to college and }\end{array}$


did not want to leave Palopo, it was better to study at my campus (Muhammadiyah Palopo University). I wondered whether this would not be a problem because this campus had a different faith from mine. After all, it was based on Islam. Finally, I tried to make observations and dig for more in-depth information about the Muhammadiyah University of Palopo.

\begin{tabular}{cl}
\hline $\begin{array}{c}\text { CSY } \pm \text { 21 years Old } \\
\text { Women }\end{array}$ & $\begin{array}{l}\text { My parents did not allow me to study outside the Palopo } \\
\text { area. But since high school, I had intended to look at the } \\
\text { Muhammadiyah University of Palopo. }\end{array}$ \\
\hline $\begin{array}{c}\text { TA } \pm 19 \text { years Old } \\
\text { Women }\end{array}$ & $\begin{array}{l}\text { Initially, I intended to go to Makassar to continue my } \\
\text { study, but due to several considerations that maybe by } \\
\text { studying at Muhammadiyah University of Palopo I did not } \\
\text { need to be far from my parents. }\end{array}$ \\
\hline $\begin{array}{c}\text { RZW } \pm 19 \text { years Old } \\
\text { men }\end{array}$ & There was no difficulty. \\
\hline $\begin{array}{c}\text { FEB } \pm 19 \text { years Old } \\
\text { Women }\end{array}$ & $\begin{array}{l}\text { Initially, I enrolled in two official bond universities. But I } \\
\text { was not accepted. }\end{array}$ \\
\hline
\end{tabular}

\section{Problem Identification: The Best Decision}

Table 2: Interview Result Problem Identification: The Best Decision

\begin{tabular}{cl}
\hline Informant & \multicolumn{1}{c}{ Description } \\
\hline $\begin{array}{c}\text { APR } \pm 22 \text { years Old } \\
\text { Women }\end{array}$ & $\begin{array}{l}\text { I try to make observations and dig for more in-depth } \\
\text { information about Muhammadiyah University of Palopo. It } \\
\text { turned out that after searching for the information and } \\
\text { observations, I concluded that Muhammadiyah Palopo } \\
\text { University was the right choice for me. }\end{array}$ \\
\hline CSY \pm 21 years Old & - \\
Women & $\begin{array}{l}\text { Through several considerations, maybe by studying at } \\
\text { the Muhammadiyah University of Palopo, I did not need } \\
\text { to stay away from my parents. }\end{array}$ \\
\hline Women & $\begin{array}{l}\text { Since the third grade of high school, I was sure to } \\
\text { choose Muhammadiyah Palopo University. This } \\
\text { decision became the best choice after getting brochures } \\
\text { from a cousin who also studied at the PAUD Study } \\
\text { Program, Muhammadiyah University of Palopo. }\end{array}$ \\
\hline Men & $\begin{array}{l}\text { Since I was not accepted into two colleges with official } \\
\text { ties, a whisper emerged that even though I studied at } \\
\text { Muhammadiyah University of Palopo I could still build } \\
\text { good relationships. }\end{array}$ \\
\hline Women & years Old
\end{tabular}




\section{Problem Identification: Decision Making Process}

Table 3: Interview Reslut Problem Identification: Decision Making Process

\begin{tabular}{cl}
\hline Informant & \\
\hline APR \pm 22 years Old & The process was quite long. Through the discussion \\
Women & process, first with friends. Then I have to communicate \\
& with my family first. After obtaining approval from my \\
& family, I did not immediately decide to enter \\
& Muhammadiyah University of Palopo. I had to think \\
& again, remembering that Muhammadiyah University of \\
& Palopo is an Islamic campus while I am a non-Muslim. \\
& Until finally, I looked for information first by observing \\
& friends who studied at Muhammadiyah Palopo University. \\
& This direct observation made me even more convinced \\
& that I said that the Muhammadiyah University of Palopo \\
& was not wrong. \\
\hline CSY \pm 21 years Old & $\begin{array}{l}\text { The process was not that difficult for me because from the } \\
\text { Women }\end{array}$ \\
start. I had intended to enter the Muhammadiyah \\
University of Palopo. Apart from that, what became my \\
basis for choosing Muhammadiyah Palopo University was \\
because the only department I wanted to choose was at \\
the Muhammadiyah University of Palopo even though \\
there are many campuses in Palopo City.
\end{tabular}

PERCEPTION AND MOTIVATION OF CHRISTIAN STUDENTS TO CHOOSE MUHAMMADIYAH (IMAM \& ASRIANY) 7 


\section{Problem Identification: Constraints to Decision Making}

Table 4: Interview Result Problem Identification: Constraints to Decision Making

\begin{tabular}{|c|c|}
\hline Informant & Description \\
\hline $\begin{array}{c}\text { APR } \pm 22 \text { years Old } \\
\text { Women }\end{array}$ & - \\
\hline $\begin{array}{c}\text { CSY } \pm 21 \text { years Old } \\
\text { Women }\end{array}$ & $\begin{array}{l}\text { The obstacle there was more of a feeling actually } \\
\text { because the University of Muhammadiyah Palopo is a } \\
\text { university with Islamic nuances. There were whispers } \\
\text { that I would feel abandoned that day. But because I } \\
\text { remembered my parents who gave me support, I was } \\
\text { still enthusiastic. }\end{array}$ \\
\hline $\begin{array}{l}\text { TA } \pm 19 \text { years Old } \\
\text { Women }\end{array}$ & - \\
\hline $\begin{array}{l}\text { RZW } \pm 19 \text { years Old } \\
\text { Men }\end{array}$ & \\
\hline $\begin{array}{l}\text { FEB } \pm 19 \text { years Old } \\
\text { Women }\end{array}$ & $\begin{array}{l}\text { Constraints from families usually questioned why I } \\
\text { wanted to enter campus on an Islamic basis. }\end{array}$ \\
\hline
\end{tabular}

\section{Supporting Factors: Family Support}

Table 5: Interview Result Supporting Factors: Family Support

\begin{tabular}{|c|c|}
\hline Informant & Description \\
\hline $\begin{array}{l}\text { APR } \pm 22 \text { years Old } \\
\text { Women }\end{array}$ & $\begin{array}{l}\text { Although I decided to enroll at Muhammadiyah } \\
\text { University of Palopo, which is based on Islam, my } \\
\text { family and friends supported me. }\end{array}$ \\
\hline $\begin{array}{l}\text { CSY } \pm 21 \text { years Old } \\
\text { Women }\end{array}$ & $\begin{array}{l}\text { The person who supported me the most was my } \\
\text { brother. }\end{array}$ \\
\hline $\begin{array}{c}\mathrm{TA} \pm 19 \text { years Old } \\
\text { Women }\end{array}$ & My parents were indeed very supportive of me. \\
\hline $\begin{array}{l}\text { RZW } \pm 19 \text { years Old } \\
\text { Men }\end{array}$ & $\begin{array}{l}\text { My father supported me the most in the decision to } \\
\text { choose Muhammadiyah Palopo University. }\end{array}$ \\
\hline $\begin{array}{l}\text { FEB } \pm 19 \text { years old } \\
\text { Women }\end{array}$ & $\begin{array}{l}\text { My parents supported me, Sir, but the one who } \\
\text { supported me more was my brother. }\end{array}$ \\
\hline
\end{tabular}

\section{Purpose: Purpose of Decision Making}

Table 6: Interview Result Purpose: Purpose of Decision Making

\begin{tabular}{cl}
\hline Informant & \multicolumn{3}{c}{ Description } \\
\hline $\begin{array}{c}\text { APR } \pm 22 \text { years Old } \\
\text { Women }\end{array}$ & $\begin{array}{l}\text { More on motivation to add to the repertoire of } \\
\text { knowledge. }\end{array}$ \\
\hline
\end{tabular}




\begin{tabular}{|c|c|}
\hline $\begin{array}{c}\text { CSY } \pm 21 \text { years Old } \\
\text { Women }\end{array}$ & $\begin{array}{l}\text { The underlying objective was actually to study because in } \\
\text { Palopo only Muhammadiyah University of Palopo has a } \\
\text { major in accounting. }\end{array}$ \\
\hline $\begin{array}{l}\mathrm{TA} \pm 19 \text { tahun } \\
\text { Perempuan }\end{array}$ & $\begin{array}{l}\text { One of the goals was to develop oneself through learning } \\
\text { at the Muhammadiyah University of Palopo. }\end{array}$ \\
\hline $\begin{array}{l}\text { RZW } \pm 19 \text { years Old } \\
\text { Men }\end{array}$ & $\begin{array}{l}\text { The underlying objective was to develop knowledge } \\
\text { about physical education and health research. }\end{array}$ \\
\hline $\begin{array}{l}\text { FEB } \pm 19 \text { years Old } \\
\text { Women }\end{array}$ & To explore accounting science. \\
\hline
\end{tabular}

\section{Purpose: Hope After Graduation}

Table 7: Interview Result Purpose: Hope After Graduation

\begin{tabular}{cl}
\hline Informant & \multicolumn{1}{c}{ Description } \\
\hline APR \pm 22 years Old Women & To be a successful person. \\
\hline CSY \pm 21 years Old Women & Can be a successful person. \\
\hline TA \pm 19 years Old Women & Can work (become a teacher). \\
\hline RZW \pm 19 years Old Men & Can be successful by becoming a teacher. \\
\hline FEB \pm 19 years Old Women & Can be a successful accountant. \\
\hline
\end{tabular}

Herawaty \& Wulan (2013) justified the statement that the family function at the adolescent development stage has a vital role in adolescents' quality. Briones \& Bueno (2019) defined five main important factors in selecting a school or university: parents, economic status, school/college accreditation, tuition/college fees, and employment opportunities that are available when somebody decided to join the university. Matsolo, Ningpuanyeh, \& Susuman (2016) argued that financial, orphan status, and transportation to schools/colleges are the main factors that influence the decision to enroll a university.

This research's novelty comes from a pluralistic theme that is currently being discussed because it is related to religious harmony. This research is very important as a reference to provide information about the views of non-Muslims towards the existence of higher education institutions that are based on Islamic religious values.

\section{CONCLUSION}

Christian students' perception and motivation in enrolling Muhammadiyah University of Palopo were highly influenced by some factors such as the support from parents, family, self-motivation, and the desired major at Muhammadiyah University of Palopo. The researchers suggest that educational institutions should transform religious life by looking at Ilahiyah (religious) aspects and socio-cultural aspects. Education is expected to maintain the nation's culture and then bequeath it to the next generation, including values, brotherhood in diversity, awareness of diversity unity, maintaining and understanding mutual respect, and prioritizing open-mindedness in every problem faced.

PERCEPTION AND MOTIVATION OF CHRISTIAN STUDENTS TO CHOOSE MUHAMMADIYAH (IMAM \& ASRIANY) 9 
Education must be capable of meeting boundaries of primordialism, race, ethnicity, and religion due to facing a pluralistic framework of life.

\section{REFERENCES}

Amirsyah. (2012). Meluruskan salah paham terhadap deradikalisasi pemikiran, konsep dan strategi pelaksanaan. Jakarta: Grafindo Khazanah Ilmu.

Anwar, S. (2018). Manhaj Tarjih Muhammadiyah. Tajdida: Jurnal Pemikiran Dan Gerakan Muhammadiyah, 16(1), 1-23. http://journals.ums.ac.id/index.php/tajdida/article/view/7606.

Asroni, A. (2007). Membendung Radikalisme Islam: Upaya Merajut Kerukunan Antar Umat Beragama, dalam Erlangga Husada, dkk. Kajian Islam Kontemporer. Jakarta: Lembaga Penelitian UIN Syarif Hidayatullah.

Biyanto, B. (2014). Pengalaman Muhammadiyah Membumikan Nilai-nilai Pluralisme. ISLAMICA: Jurnal Studi Keislaman, 7(2), 318-339. https://doi.org/10.15642/islamica.2013.7.2.318-339.

Briones, E. R., \& Bueno, D. C. (2019). Factors affecting the decision of first year students in choosing their degree program and school. Institutional Multidisciplinary Research and Development Journal, 2, 130-135. https://doi.org/10.13140/RG.2.2.25060.01921.

Dowd, R. A. (2015). Religious Diversity and Religious Tolerance: Lessons from Nigeria. Journal of Conflict Resolution. https://doi.org/10.1177/0022002714550085.

Faas, D., Darmody, M., \& Sokolowska, B. (2015). Religious diversity in primary schools: reflections from the Republic of Ireland. British Journal of Religious Education, 8398. https://doi.org/https://doi.org/10.1080/01416200.2015.1025700.

Herawaty, Y., \& Wulan, R. (2013). Hubungan antara keberfungsian keluarga dan daya juang dengan belajar berdasar regulasi diri pada remaja. Jurnal Psikologi, 9(2), 138-147. http://dx.doi.org/10.24014/jp.v9i2.176.

Ilyas, Y. (2005). Pluralisme Agama dalam Perspektif Islam. Pemikiran Muhammadiyah: Respon terhadap Liberalisasi Islam. Surakarta.

Kahar, M. S., \& Pabalik, D. (2018). Profil Pendidikan Karakter Mahasiswa Non Muslim dalam Implementasi Al-Islam dan Kemuhammadiyahan. AL-HAYAT: Journal of Islamic $\quad$ Education, 2(1), 79-88. https://alhayat.or.id/index.php/alhayat/article/view/21.

Kuntowijoyo. (2008). Paradigma Islam: interpretasi untuk aksi. Jakarta: Mizan.

Kurnianto, H., \& Kasturi, T. (2016). Pengambilan Keputusan Mahasiswa Non Muslim Untuk Studi di Perguruan Tinggi Islam. Semantic Scholar.

Lestari, G. (2016). Bhinnekha Tunggal Ika: Khasanah Multikultural Indonesia Di Tengah Kehidupan SARA. Jurnal Pendidikan Pancasila Dan Kewarganegaraan, 28(1). http://dx.doi.org/10.17977/jppkn.v28i1.5437.

Mariati. (2017). Motivasi Mahasiswa Non Muslim Studi di Universitas Islam Negeri Sultan Syarif Kasim (Studi Fakultas Tarbiyah dan Keguruan 2015/2016). JOM FISIP, 4(1), 1-13. https://www.neliti.com/id/publications/200328/motivasi-mahasiswanon-muslim-studi-di-universitas-islam-negeri-sultan-syarif-ka. 
Matsolo, M. J., Ningpuanyeh, W. C., \& Susuman, A. S. (2016). Factors affecting the enrolment rate of students in higher education institutions in the Gauteng province, South Africa. Journal of Asian and African Studies. https://doi.org/10.1177/0021909616657369.

Mu'ti, A. (2016). Akar pluralisme dalam pendidikan Muhammadiyah. Afkaruna: Indonesian Interdisciplinary Journal of Islamic Studies, 12(1), 1-42. https://doi.org/10.18196/aiijis.2016.0053.1-42.

Muhammadiyah, P. P. (2010). Tanfidz Keputusan Muktamar Satu Abad Muhammadiyah. Yogyakarta: Pimpinan Pusat Muhammadiyah.

Muhammadiyah, P. P. (2015). Tanfidz Keputusan Muktamar Muhammadiyah ke-47. In Berita Resmi Pimpinan Pusat Muhammadiyah (p. 80).

Nashir, H. (2006). Meneguhkan ideologi gerakan Muhammadiyah. UPT Penerbitan Universitas Muhammadiyah, Malang.

Pajarianto, H., \& Mahmud, N. (2019). Model Pendidikan dalam Keluarga Berbasis Multireligius. Lentera Pendidikan: Jurnal Ilmu Tarbiyah Dan Keguruan, 22(2), 254266. https://doi.org/10.24252/lp.2019v22n2i7.

Pratiwi, I. S. (2009). Hubungan antara Pengambilan Keputusan dengan Rokrastinasi Akademik pada Mahasiswa. Prodi Psikologi UNIKA Soegijapranata.

Pribadi, I., Halim, I., Batlajery, S., \& Raf, N. (2019). The Implementation of Integrated Local Wisdom based Curriculum in Enhancing Environmental Education. IOP Conference Series: Earth and Environmental Science, 343(1), 12159. https://iopscience.iop.org/article/10.1088/1755-1315/343/1/012159.

Shakeel, M. D. (2018). Islamic Schooling in the cultural West: A Systematic Review of the Issues Concerning School Choice. Religions, 9(12), 1-31. https://doi.org/10.3390/rel9120392.

Soetapa, D. (1991). Ummah: Komunitas Religius, Sosial dan Politik dalam Al-Qur'an. Yogyakarta: Duta Wacana University Press dan Mitra Gama Widya.

Tamrin, M. (2019). Al-Islam Dan Kemuhadiyahan (AIK) Pilar Dakwah Islam Rahmatan Lil Alamin (Studi Pada Perguruan Tinggi Muhammadiyah Di NTT). TA'LIM: Jurnal Studi Pendidikan Islam, 2(1), 69-87. https://doi.org/10.29062/ta'lim.v2i1.1299.

Utami, S. R. (2018). Implementasi Nilai-nilai Toleransi antar Umat Beragama pada Lembaga Pendidikan Non Muslim (Studi Kasus di SMP Pangudi Luhur Salatiga Tahun Pelajaran 2017/2018). IAIN Salatiga.

Wakhidah, N. J. I., \& Adityarini, H. (2020). How Do International Non-Muslim Students at Islamic University in Indonesia Cope With the Culture Shock During Their Studies? Advances in Social Science, Education and Humanities Research, 461, 103-107. https://doi.org/10.2991/assehr.k.200804.019.

Yahya, M. (2010). Pendidikan Islam Pluralis dan Multikultural. Lentera Pendidikan: Jurnal Ilmu Tarbiyah Dan Keguruan, 13(2), 175-191. https://doi.org/10.24252/lp.2010v13n2a5. 